\title{
NEWS OF THE EUROPEAN BISON IN POLAND *
}

\author{
From Professor KazimiERz KRYSIAK \\ April, 1963
}

\begin{abstract}
During the first world war all the bison in the Białowieża Forest were destroyed but a new chapter in the history of the species started in 1929 with the introduction of captive stock. An area of 500 acres in the forest was fenced and 70 acres of it deforested. Thirty-two bison were living in this closed reserve on 31st December, 1962.

In 1956 a number of bison were released to freedom in the Białowieża Forest. This herd now consists of fifty-seven animals of which thirty-four were born and bred in the wild. This new experiment of the herd living free is a novelty and worthy to be discussed in detail.

Several decades of breeding under reserve conditions had the unavoidable result of semi-domestication. Now the problem is to restore the bison to its wild state and to include it into the natural biocoenosis. Although the experiment has lasted only a short time, the results so far are encouraging.

Of course the fact of having a free herd does not mean that the breeding herd in the fenced area will be unnecessary. It will be continued as a safeguard.
\end{abstract}

\section{The Free Herd}

The habits of the free herd are of course less well known than those in the fenced area and are given below in brief according to the paper by Julian Scibor in Chronmy Przyrode Ojczysta (The Protection of Nature), Num. 3, 1961.

The bison enjoy living free very much. They are in an excellent state, better than those under reserve breeding.

In time of rutting the herd is divided into small groups of eight to twelve head. Usually it is the oldest cow which is the leader. During winter and spring all the small groups join into the one common herd but the old bulls keep at a distance and live in a separate group.

Throughout the winter the bison are supplied with $8 \mathrm{~kg}$. of hay a day per head because it has been stated that the animals left to themselves lose weight in winter. There are three permanent feeders in the Białowieża Forest. The cows and calves gather at two feeders, while old bulls feed separately at the other one.

The bison like to eat up the bark of common sallow, poplar and European aspen, subsequently the bark of lime and other broadleaved trees, for example maple and ash. They hardly eat at all the bark of birch but sometimes browse the sprouts of young spruces and pines. The bison like to eat the oak bark at the root collar. Acorns are their favourite food and in the acorn season the bison eat nothing else, and do not strip the trees. Indisposed bison do not eat anything but the bark of common sallow.

* See also "Nature Conservation in Poland", Oryx, VI, 1, pp. 6-26. 
The hair-shedding period occurs regularly. In summer the coat is dark brown and glittering, in winter it is somewhat lighter, like hoar-frost.

The bison do some damage especially to young forests but comparatively less than the losses inflicted by smaller game. It is believed that two bison can live on every 1,000 hectares ( 4 square miles) without any visible damage to the forest stand, so the Białowieża Primeval Forest is capable of supporting 100 to 115 bison.

The gestation period is 260 to 270 days. Renewed impregnation is normally noted 100 days after parturition, but it has been observed after twelve days and up to five months.

The observations made on the bison under reserve conditions with regard to its irregular process of reproduction indicate that this irregularity is an effect of semi-domestication. It appears that parturition can take place in any month of the year; however, procreation occurs most often in May-about 33 per cent, in June 20 per cent, in July 13 per cent and an average of several per cent in the remaining months.

The bison grows slowly. It has been thought that at the age of six the animal reaches full physical development, but it grows and increases in weight up to the age of eight or nine. Sexual attraction is displayed at the age of two. Under reserve conditions the practice was to use three-year-old cows for reproduction so as to make them have their first calf at the age of four.

The breeding practice as well as the observations of bison in the wild proved that the proper sex ratio should be 1 to 3 or 1 to 4 . As the sex ratio of the offspring is maintained at 1 to 1 , there is an excess of males for breeding. They may be of use to us as demonstrative exhibits or for research purposes; nevertheless the excess of males in large breeding centres becomes a problem.

The bison can reach twenty years of age and more. A new-born calf weighs about $40 \mathrm{~kg}$. and measures $70 \mathrm{~cm}$. in height. A mature cow weighs about $600 \mathrm{~kg}$. ; a bull weighs up to $1,000 \mathrm{~kg}$., its length is about $3.5 \mathrm{~m}$., the height at withers is up to $2 \mathrm{~m}$. Females are less.

The common opinion about bisons' malignity is exaggerated. They are dangerous during rutting time and so is the female shortly after parturition. The only sound the bison gives out is " snorting ". The tone of snorting varies; it sounds different in rutting time, when the female is calling the calf or when the animal is irritated.

The total number of bison in Poland as on 31st December, 1962, was 178 animals and this country is still the world's leading centre in bison breeding. The breeding reservations are at Białowieża, Pszczyna, Niepołomice, Borki, Smardzewice. Single specimens are kept in zoological gardens.

The Polish experience is that the wider the distribution of the bison over the country reserves, the better results of safeguarding it against cataclysms and epizootics.

In order to maintain the European bison as a species, Poland has begun to supply bison abroad, not only in Europe but also out of Europe.

The total number of the European bison as on 1st January, 1959, was 361, distributed thus : Poland 119, U.S.S.R. 94, Germany 43, Sweden 34, 
the Netherlands 16, Czechoslovakia 10, Belgium 6, Denmark 5, Austria 4, France 3, Hungary 3, Yugoslavia 2, Switzerland 2, Finland 3, Bulgaria 1, U.S.A. 11, Rumania 2, England 3.

In that total number of 361 there are 188 females and 173 males. The present distribution of the bison excluding some rare exceptions more or less covers its historical range.

The favourable result of bison breeding under reserve conditions has removed the danger of the total extermination of the European bison. It is difficult to say whether the experiment started in 1956 will make it possible to return the bison completely to its natural biocoenosis. The hardest obstacle in the way of the solution of this problem is contemporary rational forest management.

\section{LITERATURE}

1. JACZEWSKI, Z. Rozród żubra w warunkach rezerwatowych (Reproduction of the European bison in reserves). Acta Theriol. vol. I, Nom. 9, pp. 333-76, Warszawa, 1958.

2. Pedigree Book of the European Bison. Published by the International Society for the Protection of the European Bison, Warszawa, 1, I, 1959.

3. Krysiak, K. The European Bison (Bison bonasus). State Council for Conservation of Nature, Poland, Nom. 10, Kraków, 1960.

4. MoHr, E. Der Wissent. Akad. Verlagsgesell. Leipzig, 1952.

5. SciBor, J. Zubry w Puszczy Białowieskiej (The Bisons in the Białowieża Primeval Forest). Chronmy Przyrode Ojczysta (Protection of Nature), Nom. 3, pp. 16-26, PWN. Warszawa, 1961.

6. Wróblewski, K. Żubr Puszczy Białowieskiej (The Bison of the Białowieża Forest). Wyd. Polskie, Poznań, 1927. 